\title{
Comparative Study of Issuing Bank's Obligations towards Beneficiary of the Letter of Credit under UCP and English Law
}

\author{
Hamed Alavi \\ Faculty of Law, Universitat Autònoma de Barcelona \\ Campus de la UAB, Plaça Cívica, s/n, 08193 Bellaterra, Barcelona, Spain. \\ Tel./Fax:+34935811111E-mail: hamed.alavi@ttu.ee \\ Submitted: Jul 11, 2016; Reviewed: Sep 25, 2016; Accepted: Oct 6, 2016
}

\begin{abstract}
Process of international trade is complicated and risky. Risks will be more considerable when times come to deal with receiving/sending payments from/to unknown business partners in remote geographic areas. Employing documentary letters of credit $(L C)$ is one of the ways to reduce payment risk in international business especially when partner's financial standing is unknown to each other. By using the LC as method of payment, parties will shift payment obligation from buyer as a natural person to the guarantee of bank as a legal person. The process of using LC is complicated and involves different players and relations between them. Amongst all relations in process of LC transaction, relation between issuing bank and beneficiary is the most complicated and least clear from legal stand point. This article tries to shed light on vague aspects of relations between issuing bank and beneficiary by studying obligations of the issuing bank towards beneficiary under the law of documentary letters of credit while comparing provisions of UCP with English Common Law on subject matter. Main objective of paper is providing answer to the question of what is the role of issuing bank in the process of LC transaction and which liabilities does it have towards beneficiary? Article consists of five main parts. Part one will provide an introduction to function and relation among different parties in process of an international LC transaction. Further, it endeavours to tap on principle of autonomy and strict compliance as governing principles of documentary letters of credit. Part two and three will take a comprehensive look at legal basis of relations between issuing bank and beneficiary, as well as bank's obligations under documentary credit law. Part four will discuss liabilities of issuing banks towards beneficiary and finally part five will touch upon situation in which bank will right to recourse against beneficiary.
\end{abstract}

Keywords: Beneficiary; Documentary Letters of Credit; English Law; Issuing Bank; Obligations; Uniform Customs and Practice

DOI: 10.20956/halrev.v2i3.259

\section{INTRODUCTION}

While being engaged in international business, seller looks for minimizing the payment risk subsequent to delivery of goods by receiving either cash in advance or payment on delivery or where the buyer's interest is to pay only after being certain about receiving goods in accordance with contract of sales. ${ }^{1}$ Additionally, reasons including: lack of familiarity with other

Carr, I., \& Stone, P. (2014). International Trade Law, 5th Edition. New York: Routledge, p. 65. 
party's financial standing ${ }^{2}$ possibility for either party to default in the course of business transaction, geographical distance of parties $^{3}$, difference in national currencies, need for intermediaries ${ }^{4}$, multi-jurisdictional nature of the transaction ${ }^{5}$ are behind decision of parties to use documentary letters of credit as a method of payment in their international transaction. LC is a written undertaking by a bank which assumes primary and absolute liabilities of buyer (applicant) and promises to pay the beneficiary (seller) to pay in accordance with terms of underlying contract of sales previously negotiated between him and the applicant. ${ }^{678}$

Since the buyer and seller in an international contract are generally in different countries, in the process of LC transaction, it is popular to include a fourth party from the country of beneficiary, namely a bank known as corresponding bank. ${ }^{9}$ According to Uniform Customs and Practices for Documentary Credits (currently UCP 600), different functions for corresponding bank ${ }^{10}$ are:

2 Grassi, P. (2006). "Letter of Credit Transactions: The Banks' Position in Determining Documentary Compliance. A Comparative Evaluation under U.S., Swiss and German Law", Pace International Law Review, 7(81), 122.

3 Leacock, S.J. (1984). "Fraud in the International Transaction: Enjoining Payments of Letters of Credit in International Transactions", Vand. J. Transnatl. L. 17, 898.

4 Bollen, R. (2007). "An Overview of the Operation of International Payment Systems with Special Reference to Australian Practice: Part 1", Journal of International Banking Law and Regulation, 22 (7), 381.

Ibid, p. 379

6 Lipton, J.D. (1998). "Documentary Credit Law and Practice in the Global Information Age", Fordham International Law Journal, 22(5): 1972-1990.

7 Megrah, M. (1982). "Risks Aspects of the Irrevocable Letter of Credit", Ariz. L. Rev. 24, 260.

8 Goode, R, (1988). "Surety and On-Demand Performance Bonds", J. Bus. L. 88.

9 Jack, R. (2003). Documentary Credits: The Law and Practice of Documentary Credits Including Standby Credits and Performance Bonds. UK: Butterworths.

10 Article 2, UCP 600. acting as advising bank, nominated bank, negotiating bank and confirming bank. By confirming the credit, confirming bank assumes same liabilities as issuing bank towards beneficiary and relieves him from certain degree of risk which may result in not effectuating payment by issuing bank in accordance with terms and conditions of the credit. ${ }^{11}$ Autonomy principle and strict compliance as two main governing principles of LC provide that in effectuating the payment, issuing bank does not look into the performance of beneficiary in the framework of underlying contract $^{12}$ and beneficiary is only supposed to produce complying presentation of documents stipulated in the LC to receive payment from either of issuing or confirming bank. ${ }^{13}$ Any claim regarding performance of beneficiary under the contract of sales should be followed separately as banks deal only with documents and not goods. ${ }^{14}$

According to Kudrianchov, ${ }^{15}$ the LC is a "complex of contractual obligations". Lord Diplock in United City Merchants (Investments) Ltd. v. Royal Bank of Canada ${ }^{16}$ defines the relations under the letter of credit as four autonomous but interrelated contracts:

11 Zhou. L. (2002). "Legal Position between Advising Bank and Confirming Bank: Contrast and Comparison", Journal of International Banking Law, 17(7): 226; McCormack G et al., (2000) Subrogation and Bankers' Autonomous Undertakings, 116 Law Quarterly Review 141.

12 Ellinger, P.E (1983), "The Autonomy of Letters of Credit after the American Accord", Australian Business Law Review, 11(2), 118

13 Buckley, R et al., (2002). "Development of the Fraud Rule", 23 U. Pa. J. Int'l Econ. L. 698

14 Neo, D.S.S. (2004). "A Nullity Exception in Letters of Credit Transactions?" Singapore Journal of Legal Studies, 49.

15 Schmitthoff, C.M. (1988). "The Transferable Credit", Journal of Business Law, 51 .

16 United City Merchants (Investments) Ltd. v. Royal Bank of Canada, [1932] 2 W.L.R. 1039, H.L. 
"...it is trite law that there are four autonomous though interrelated contractual relations involve:

(1) Underlying contract for the sale of goods, to which the only parties are the buyer and the seller;

(2) The contract between buyer and the issuing bank under which the latter agrees to issue the credit and either itself or through a confining bank to notify the seller and to make payments to or to the order of the seller (or to pay, accept or negotiate bills of exchange drawn by the seller) against presentation of stipulated documents; and the buyer agrees to reimburse the issuing bank for payment made under the credit. For such reimbursement, stipulated documents, if they include a document of title such as bill of lading, constitute a security available to the issuing bank;

(3) If payment is to be made through a confirming bank, bank authorizing and requiring the later to make such payments and to remit the stipulated documents to the issuing bank when they are received, the issuing bank in turn agrees to reimburse the confirming bank for payments made under the credit;

(4) The contract between the confirming bank and the seller under which the confirming bank undertakes to pay the seller (or to accept or negotiate without recourse to drawer of bills of exchange drawn to him) up to the amount of the credit against presentation of the stipulated documents". ${ }^{17}$

Interestingly, Lord Diplock does not give any reference to the contract between issuing bank and seller. This issue has been noticed by Raymond Jack. ${ }^{18}$ Therefore, it is

17 Ibid, p. 182-183

18 Malek, A, Quest. D, (2009). Jack: Documentary Credit: The Law and Practice of Documentary Credit including possible to mention that there are five autonomous but interconnected contracts between parties in the system of international documentary letter of credit. Among them, scholars mostly debate on legal nature of relations between issuing bank and beneficiary.

Issuing bank-beneficiary relations and its liabilities towards beneficiary as the centre of focus in current paper are important since the legal basis for their relation is not clear in different legal systems. UCP does not provide any precise definition on legal nature of relations between issuing and confirming bank with beneficiary in LC system. ${ }^{19}$ English law has never taken a thorough approach to relations between issuing bank and the beneficiary. ${ }^{20}$ In a way, Gutteridge and Megrah consider it as an unresolved issue. ${ }^{21}$ Such uncertainty in legal basis of obligations of issuing bank towards beneficiary creates troubles on the way to study rights and liabilities of them against each other.

Current paper tries to clarify the legal nature of relations between issuing bank and beneficiary and explain obligations of issuing bank towards beneficiary based on extensive comparative research in existing literature on subject matter as well as case law available under English law. In doing so, part one of the paper will explain the procedure of functioning of the documentary letter of credit and its main principles. Part two will focus on duty of beneficiary on

Standby Credits and Demand Guarantees, 4th Ed, UK Tottel Publishing, p. 90.

19 Hugo, C. (2000). "Documentary Credits: The Basis of the Bank's Obligation". S. African LJ, 117, 224.

$20 \quad$ Ibid, p. 231

21 Gutteridge, H.C., Megrah, M. (1984). The Law of Bankers' Commercial Credits. $7^{\text {th }}$ ed, London: Europa Publications Ltd, p. 34. 
presentation of documents. Part three will define obligations of the issuing bank and tap on legal basis of issuing banks obligations towards beneficiary. Finally, part four will explain conditions under which issuing bank has the right for recourse against beneficiary.

\section{ANALYSIS AND DISCUSSION}

Functioning Process of the Documentary Letter of Credit

As it has been mentioned before, function of the documentary letters of credit involves four independent but interrelated contracts. Parties to contracts are buyer (applicant), seller (beneficiary), issuing/confirming bank, negotiating and/or nominated bank which makes the payment. In fact, process of international LC transaction starts by agreement of buyer and seller in their underlying contract of sales to include a clause which defines documentary letter of credit as method of payment in their trade. Then the buyer approaches issuing bank in order to open LC in favour of beneficiary. In case of issuing bank's agreement, LC will be issued and advised to the beneficiary either by issuing bank or her correspondent in beneficiary's country named as "advising bank". ${ }^{22}$

In case beneficiary seeks for further reduction of risk, he might require the guarantee of second bank on the credit which will involve "confirming bank" in the LC transaction. ${ }^{23}$ In order to receive payment, beneficiary should present complying documents stipulated in the credit either to issuing bank or her correspondent (nominated, advising bank) or to confirming bank. Receiv22 UCP 600, Article 2.

23 Ibid. ing bank will check documents and in case of their conformity with term of the credit, documents will be forwarded to the issuing bank for another round of checking. In case issuing bank finds presentation complying, beneficiary will be paid and applicant will be informed to take documents. Bank will be reimbursed if applicant finds documents in compliance with terms of credit. Despite the fact that UCP separates the credit from its underlying contract, ${ }^{24}$ court in Garcia v. Page \& Co. Ltd. ${ }^{25}$ held that opening the credit mentioned in the underlying contract is condition precedent for shipping goods by seller. Also if the date for opening the credit has been defined in contract of sales, applicant should comply with it otherwise beneficiary has the right to cancel the contract based on buyer's repudiation. In case of Pavia \& Co SpA v. Thurmann-Nielsen, ${ }^{26}$ where contract of sales had no reference to date of opening of the credit, the Court of Appeal held that buyer should provide the seller with credit before the starting of shipment period. Therefore, he will be sure that payment is secured and there will be not further financial risks involved in that particular transaction. ${ }^{27}$

\section{Autonomy Principle}

First fundamental principle in operation of letters of credit is Principle of Autonomy. This principle has been appreciated in national and international legal frameworks. ${ }^{28}$ The principle of autonomy of letters of

\footnotetext{
UCP 600, Article 4.

(1936) 55 LI.LR 391.

(1952) 2 Q.B. 84.

Ibid.

28 Article 4 UCP 600; Article 2(b) URDG; Articles 2 and

3 UNCITRAL-Convention; Sections 5-10 (1)(a), 5-114

(1) and 5 5-103(d) UCC.
} 
credit has been considered as "cornerstone of the commercial validity of the letters of credit", ${ }^{29}$ and "the engine behind the letter of credit". ${ }^{30}$ The autonomy principle of letter of credits has been clearly mentioned in Article 4 of UCP 600 :

Article 4 Credits v. Contracts:

(a) A credit by its nature is a separate transaction from the sale or other contract on which it may be based. Banks are in no way concerned with or bound by such contract, even if any reference whatsoever to it is included in the credit. Consequently, the undertaking of a bank to honour, to negotiate or to fulfil any other obligation under the credit is not subject to claims or defences by the applicant resulting from its relationships with the issuing bank or the beneficiary. A beneficiary can in no case avail itself of the contractual relationships existing between banks or between the applicant and the issuing bank.

(b) An issuing bank should discourage any attempt by the applicant to include, as an integral part of the credit, copies of the underlying contract, proforma invoice and the like.

Based on Autonomy Principle and the text of Article 4 of UCP 600, the beneficiary exporter has assurance that his payment will be due upon presentation of complying documents to the issuing bank while neither bank nor the account party can deny payment based on the arguments related to performance of underlying contract. Therefore, even in case of argument on performance of

\footnotetext{
29 Ward Petroleum Corp. v Federal Deposit Ins. Corp. (1990) 903 F.2d 1299.

30 Arkins, J. (2000). Op.Cit., p. 31.
}

underlying contract account party and issuing bank have no other choice rather than paying beneficiary upon presentation of complying documents and seek remedy by suing him for the breach of underlying contract. As a result, Autonomy Principle has been considered a means of promoting international trade by following the logic of "pay first, argue later". ${ }^{31}$

The autonomy principle also has been considered as the foundation for smooth operation of letter of credits by scholars:

"We should also remember that in many international trade transactions, there are parties involved than just the buyer or seller. The seller usually had to obtain goods or raw materials from a supplier before he is able to meet the contract made with the buyer. The seller will need to be financed in making payment to their suppliers. That financing comes from the negotiation or discounting of drafts drawn under the documentary credit system. That system of financing would break down completely if a dispute between the seller and buyer was to have the effect of "freezing" the sum in respect of which the letter of credit was opened". ${ }^{32}$

In order to completely address the essence of autonomy principle, Article 5 of UCP 600 specifies: "banks deal with documents and not with goods, services or performance to which the documents may relate." ${ }^{33}$

\section{Principle of Strict Compliance}

The principle of Strict Compliance express that issuing bank's undertaking to honour

\footnotetext{
Eakin v Continental Illinois National Bank \& Trust Co. (1989) 875 F.2d 114, 116.

32 Dolan, J.F. (2006). Op.Cit., p. 480.

33 UCP 600. Article 5
} 
the credit is effective only upon presentation of complying documents which are stipulated in the credit by beneficiary. ${ }^{34}$ On the other hand, the idea of strict compliance has developed from the general principle of the law of agency that an agent is only entitled to reimbursement from his principle if he acts in accordance with his instructions. ${ }^{35}$ Therefore, banks who act as an agent for applicant in documentary credits will receive reimbursement in case of honouring the credit against presentation of complying documents. The standard for examination of documents has been set in Article 14 of UCP 600:

Article 14 Standard for Examination of Documents:

(a) A nominated bank acting on its nomination, a confirming bank, if any, and the issuing bank must examine a presentation to determine, on the basis of the documents alone, whether or not the documents appear on their face to constitute a complying Presentation.

(d) Data in a document, when read in context with the credit, the document itself and international standard banking practice, need not be identical to, but must not conflict with, data in that document, any other stipulated document or the credit."

The majority of discrepancies in practice of documentary letters of credit include inconsistent data, ${ }^{36}$ discrepant documents of transport, ${ }^{37}$ mistakes in draft, ${ }^{38}$ drafts with-

34 Interalia Article 2; Article 7(a), Article 8(a)(c) and Article 15; Article 14 and Article 34 of UCP 600

35 King, R. (2003). Gutteridge and Megrah's Law of Bankers' Commercial Credits. UK: Routledge., p. 14

Article 14(d) UCP 600

Article 19 UCP 600

8 Article 18(c) UCP 600 out signature and inconsistent invoice with credit, ${ }^{39}$ inadequate insurance, ${ }^{40}$ and documents with wrong signature. ${ }^{41}$

Contrary to the principle of independence, principle of strict compliance is protecting interests of applicant under documentary credits process which requires shipment of promised goods by beneficiary before actualization of payment. There is an ongoing scholarly debate about what constitutes the complying presentation which can be traced into legal cases. $^{42}$

Legal Basis of Issuing Bank's Obligation to Beneficiary

According to UCP, issuing bank is obliged irrevocably for honouring the credit from the moment of issuing it. ${ }^{43}$ However, it is not clear in UCP that what the time for issuance of the credit is and accordingly moment from which issuing bank will be irrevocably bound to honour the credit. Two different views exist: first view which has received support in judgment of Bunge Corp v. Vegetable Vitamin Food (Pte) Ltd., ${ }^{44}$ emphasises that credit bounds issuing bank from the exact moment that beneficiary receives advice of it. ${ }^{45}$ Second view is of the opinion that from moment beneficiary acts upon reliance on the credit make it will be binding to issuing bank. ${ }^{46}$

\footnotetext{
39 Article 28 UCP 600

40 Baker B. "Exporting Against Letters of Credit". Available online at: http://www.qfinance.com/content/Files/ QF02/g1xtn5q6/12/3/exporting-againstletters-of-credit.pdf (Accessed on 10 May 2016)

41 Article 34 UCP 600

42 Botosh, H.M.S. (2000). 'Striking the Balance Between the Consideration of Certainty and Fairness it the Law Governing Letters of Credit' $\mathrm{PhD}$ thesis, University of Sheffield, pg. 183-271.

43 UCP 600, Article 7.b

44 [1985] 1Lylod's Rep. 613

45 Malek, A, Quest. D, (2009). Op.Cit., p. 91

46 Ibid
} 
When the bank is required the issue a pre-advice, Article 11 (b) of the UCP 600 provides that:

A preliminary advice of the issuance of a credit or amendment ("pre-advice") shall only be sent if the issuing bank is prepared to issue the operative credit or amendment. An issuing bank that sends a pre-advice is irrevocably committed to issue the operative credit or amendment, without delay, in terms not inconsistent with the pre-advice.

Article 10 of the UCP 600 comments on binding nature of amendments on issuing bank and confirming bank from the moment of issuing the amendment for issuing bank and extending the confirmation to it by confirming bank.

Since UCP does not provide a precise explanation on legal basis of issuing bank's obligation to beneficiary, the matter is left to national laws. In English law, there is ambiguity in justification of contractual relations between beneficiary and issuing bank as unlike general principles of English contract law, in LC transaction, no consideration moves from the beneficiary to bank. ${ }^{47}$ However, many scholars attempted to find consideration to support the bank's obligation and introduced different theories in this regard. Three of such theories are going to be discussed here:

First is theory of offer and acceptance: This is the dominant theory in English contractual law. Accordingly, issuance of the credit by bank is the offer which might be accepted by beneficiary. ${ }^{48}$ Such contract

47 Beale, H. (2012). Chitty on Contracts. Chicago: Sweet \& Maxwell., Para. 2-019

48 Hugo, C. (2000). "Documentary Credits: The Basis of the Bank's Obligation". S. African LJ, 117, 230 is known under English law as "unilateral contract'. 49 "A unilateral contract may arise when one party promises to pay the other a sum of money if the other will do ... something without making any promise to that effect: for example, when one person promises to pay another C100 if he will walk from London to York...". ${ }^{50}$ Therefore, it is clear that in absence of beneficiary's promise, if there is a contract, it should be unilateral. Hugo explains two problems for offer and acceptance theory: "(i) the manner and time of acceptance; and (ii) whether the requirement of valuable consideration is satisfied". ${ }^{51}$ First problem rises in response to the question of time "at which the offer is "accepted" so as to deprive the offeror of the power of withdrawal". Alternatively, the question would be at what stage the unilateral promise of bank will become irrevocable? ${ }^{52}$ Some scholars reply that acceptance takes place by beneficiary while presenting stipulated documents to the issuing bank. This means acceptance will be sometimes after manufacturing or shipment of the goods. ${ }^{53}$

In contrary, other scholars argue that beneficiary accepts the offer "sometime anterior to the tender of documents". ${ }^{54}$ This view is based on decision of court in old case of Urquhart Lindsay \& Co Ltd v Eastern Bank Ltd., ${ }^{55}$ where Rowlatt J held that acceptance

49 Penn, G.A., A.M. Shea., and Arora, A. (1987). The Law and Practice of International Banking. $4^{\text {th }}$ Edition. UK: Sweet \& Maxwell, p. 296

50 Treitel, G.H. (2003). The Law of Contract. $11^{\text {th }}$ edition. UK: Sweet \& Maxwell, p. 35

51 Hugo, C. (2000), Op.Cit., p. 230

52 Todd, P. (1983). "Sellers and Documentary Credit", Journal of Business Law, 468

53 Malek. A, Quest. D, (2009). Op.Cit., p. 94

54 Davis. A.G, (1936), 'The Relationship between Banker and Seller under a Confirmed Credit', 52 LQR 225

55 [1922] $1 \mathrm{~KB} 318$ (KBD) 
is "acting upon the undertaking". ${ }^{56}$ Since Rowlatt J never defined the term "acting upon undertaking", different meanings have been suggested including: "purchasing raw materials for manufacturing" or "accepting delivery of materials necessary for production" or "taking steps to ship the goods". ${ }^{57}$ From the practical perspective, the theory does not show any merit as it is very vague about time for commencement of irrevocability and this is inconsistent with reality of LC process. ${ }^{58}$

The fact in English contract law that says consideration should "move from the promise" will make the second problem even more serious. ${ }^{59}$ Since bank does not bargain for delivery or manufacturing of goods, therefore, undertaking of the seller is not a valid consideration. ${ }^{60}$ Even sellers' obligation under the sales contract is cannot be considered as a valid consideration for bank's offer as it is known as past consideration. ${ }^{61}$ Also, "the treatment of the act of presentation as consideration is inconstant with the fundamental purpose of the credit" ${ }^{62}$ Therefore, there is no scope left for consideration in the process of LC transaction. ${ }^{63}$

\footnotetext{
$56 \quad$ Ibid

57 Hugo, C. (2000), Op.Cit., p. 230

58 Ellinger, E.P. (1970). Documentary Letters of Credit: A Comparative Study, Singapore: Singapore University Press, pg. 89-90

59 Thomas $v$ Thomas [1842] 2 QB 851 at 859; Tweddle $v$ Atkinson [1861-73] All ER Rep 369 (QB); Dunlop $v$ Selfridge [1914-15] All ER Rep 333 (HL) 334 (Viscount Haldane LC); Pollway Ltd v Abdullah [1974] 2 All ER 381 (CA).

60 McCurdy, W. (1922). "Commercial Letter of Credit", Harvard Law Review, 35, 539; King, R (ed), (2001), Gutteridge and Megrah's Law of Banker's Commercial Credit, $8^{\text {th }}$ edn, Europa Publication, p. 77.

${ }_{61}$ Dighe, K.S, (1992). "Mercantile Speciality: A Theory by which to Enforce Letters of Credit Under the Common Law". University of Detroit Mercy LR, 69, 211.

62 Cane, P, Stapleton, J (eds), (1991), Essays for Patrick Atiyah, 218

63 Ibid
}

Second theory is the agent-principle theory in which buyer is considered to be the agent of seller. However, requiring buyer to open the LC does not mean that seller intends to enter any principle-agency relations ${ }^{64}$ with him. According to Jack, "in applying to the issuing bank for the credit to be opened, the buyer was acting as his (own) agent, and there is no justification for implying any such agency". ${ }^{65}$ Additionally, if buyer acts as agent of seller, then beneficiary is responsible for all acts of applicant towards bank. If payment to bank is affected in tort or misrepresentation of applicant, then the liability will be left for beneficiary ${ }^{66}$. Even in condition that buyer has fraudulently induced bank to issue the credit, beneficiary will be liable to the bank. ${ }^{67}$ On the other hand, it can be held that since applicant acts as agent for beneficiary, there is no guarantee for applicant to prevent bank and beneficiary from changing the terms of credit. ${ }^{68}$

Third theory is based on the Contracts (Rights of the Third Party) Act $1991 .{ }^{69}$ Accordingly, this act will allow the third party to enforce a term of contract when it is: “(a) a contract expressly provides that he may; (b) term purports to confer a benefit to him". ${ }^{70}$ This theory somehow answers the question of absence of contract between beneficiary and issuing bank in English law. But, according to this theory; all beneficiary's' rights derive from the contract between

\footnotetext{
${ }_{64}$ Malek. A, Quest. D, (2009). Op.Cit., p. 95

5 Ibid

66 Ibid

67 Davis, A.G, (1963), The Law Relating to Commercial Letters of Credit, $3^{\text {rd }}$ edn, London: Isaac Pitman \& Sons Ltd, p. 19

68 Ellinger, E.P. (1970). Loc.Cit.

69 Chitty on Contracts, Para 18-120.

70 Malek. A, Quest. D, (2009). Op.Cit., p. 95
} 
applicant and bank. Actually, "the letter of credit is sent directly, or by way of a correspondent bank, to the seller and never comes into the buyer's hands at all". ${ }^{71}$ Third party rights theory also can be rejected based on two other additional arguments: First, the Credit involves two parties, namely issuing bank and beneficiary; applicant is not a party to the credit. ${ }^{72}$ Second, autonomy principle rejects the explanation of issuing bank's payment undertaking to beneficiary based on the contract between the bank and applicant.

\section{Mercantile Usage}

In 1930's Finkelstein was the first person to raise the theory of explaining relations between parties to letters of credit based on mercantile usage. ${ }^{73}$ He commented:

"[A] Letter of credit is a "mercantile specialty"... because it is governed, and throughout its history has always been governed, by the law merchant and has always been enforced by the common-law courts in accordance with the basic principles of the law merchant. Hence, the problems of consideration and of irrevocability that still bother our text writers and some of our courts would seem to be, in reality, non-existent in the law'. ${ }^{74}$

In support of this idea, Ellinger submits that it is more reliable to refer to modern mercantile usage rather than old law merchant: "a usage which treats irrevocable credits as binding from the date at which they reach the hands of the seller". ${ }^{75}$ While

\footnotetext{
71 Davis, A.G. (1963). Op.Cit., p.71

72 McKendrick, E (ed). (2010). Goode on Commercial Law, $4^{\text {th }}$ edn, London: Penguin, p. 1087

73 Hugo, C. (2000). Op.Cit., p. 234

74 Trimble, R.J. (1948). "The Law Merchant and the Letter of Credit", Harvard Law Review 61, 981-1006

75 Ellinger, E.P. (1970). Op.Cit, p. 108
}

confirming that case law in England does not provide a great support to his theory, Ellinger constructs his argument based on the counterfactual reasoning. Accordingly, the main condition for a usage to be recognized under English law is not being contradictory to Positive Law. ${ }^{76}$ Therefore, "a usage constituting an exception to a common-law principle may be acceptable or, expressed differently, whilst a usage requiring a previous decision to be overruled is unacceptable, a usage requiring that a previous decision be distinguished should be possible". ${ }^{77}$ Ellinger refers to the recognition of the law of negotiable instruments based on the mercantile usage and considers the same principle applicable to documentary letters of credit. ${ }^{78}$ Goode supports the theory of mercantile usage in explaining the obligation of issuing bank in relation with beneficiary under the letter of credit law when comments on other theories: "fall to the ground because, in an endeavour to produce an acceptable theoretical solution, they distort the character of the transaction and predicate facts and intentions at variance with what is, in practice, done and intended by the parties". ${ }^{79}$ With reference to Chitty, Jack comments on documentary letters of credit governed by English law being an exception to the rules applicable to consideration as undertakings of issuing and confirming bank to beneficiary are not supported by consideration. However, they are biding in law with reference to mercantile usage as reason for their binding nature. ${ }^{80}$

\footnotetext{
76 Ibid

77 Hugo, C. (2000). Op.Cit., p. 235

78 Ellinger, E.P. (1970). Op.Cit, p. 120

79 Goode, R. (1995). Commercial Law. $2^{\text {nd }}$ ed, London: Penguin, p. 987

80 Malek. A, Quest. D, (2009). Op.Cit., p. 93.
} 
Issuing and Confirming Banks Undertakings to Beneficiary

Article 7 and 8 of UCP 600 comment on obligations of the issuing bank as following:

Issuing Bank Undertaking:

(a) Provided that the stipulated documents are presented to the nominated bank or to the issuing bank and that they constitute a complying presentation, the issuing bank must honour if the credit is available by:

$i$. sight payment, deferred payment or acceptance with the issuing bank;

ii. sight payment with a nominated bank and that nominated bank does not pay;

iii. deferred payment with a nominated bank and that nominated bank does not incur its deferred payment undertaking or, having incurred its deferred payment undertaking, does not pay at maturity;

iv. acceptance with a nominated bank and that nominated bank does not accept a draft drawn on it or, having accepted a draft drawn on it, does not pay at maturity; v. negotiation with a nominated bank and that nominated bank does not negotiate.

(b) An issuing bank is irrevocably bound to honour as of the time it issues the credit

(c) An issuing bank undertakes to reimburse a nominated bank that has honoured or negotiated a complying presentation and forwarded the documents to the issuing bank. Reimbursement for the amount of a complying presentation under a credit available by acceptance or deferred payment is due at maturity, whether or not the nominated bank prepaid or purchased before maturity. An issuing bank's undertaking to reimburse a nominated bank is independent of the issuing bank's undertaking to the beneficiary. ${ }^{81}$

$81 \quad$ UCP 600-Article 7
UCP 600 has introduced the notion of to "honour" the credit and provided a special technical meaning for it. Therefore, to "honour" the credit means: "(a) pay at sight if credit is available by sight payment; (b) to incur the deferred payment and pay at maturity when the credit is available by deferred payment; (c) to accept the bill of exchange drawn by the beneficiary and pay at maturity if the credit is available by acceptance" ${ }^{82}$ Under UCP600, obligation to honour does not have the same meaning as obligation to negotiate. ${ }^{83}$

On the basis of Article 7(a)(ii) which is the reproduction of Article 9(a)(i) of UCP 500 , the issuing bank has the obligation to honour the credit when it is available by sight payment, deferred payment or acceptance. Article 7(a)(ii) to (v) of UCP 600 clarify the obligation of issuing bank when the credit is available with a nominated bank, but nominated bank does not act in accordance with its nomination to pay at sight, incur deferred payment or accept or negotiate the draft. In two first situations (the credit is available by sight payment or incurring deferred payment), when nominated bank does not act upon its nomination, issuing bank simply put itself in nominated bank's shoes and perform what it has failed to do by honouring the credit. ${ }^{84}$ Situation is not clear under UCP 600 when the nominated bank does not act on its nomination to accept the draft and pay in its maturity. Non acceptance of the draft drawn on nominated bank might make beneficiary to draw a fresh draft on issuing bank in order

82 UCP 600-Article 2

83 Ellinger, E.P., and Neo, D.S.S. (2010). The Law and Practice of Documentary Letters of Credit. Oxford: Hart Publishing, p. 114

84 Ibid 
to be honoured under Article 7(a). Ellinger submits that in such situation beneficiary can present the fresh draft drawn on issuing bank after the expiry date of the credit. ${ }^{85}$ Article 9(a)(iii)(b) of the UCP 500 has a more clear position which might be applicable to UCP 600 as well: Where the credit is available on acceptance with nominated bank and nominated bank rejects to accept drafts drawn in it, the issuing bank is obliged to accept and honour drafts drawn by beneficiary on it (issuing bank) on maturity. However, where the nominated bank accepts drafts drawn on it but does not honour them on maturity, issuing bank must pay on those drafts (which are drawn on nominated bank). UCP 500 provides that in second situation, beneficiary does not need to draw fresh drafts on issuing bank.

Availability of credit with nominated bank for negotiation refers to two different situations of negotiating documents under deferred payment or negotiating documents (including bill of exchange) under acceptance credit. ${ }^{86}$ Where nominated bank refuses to act upon its nomination and negotiate documents, issuing bank is obliged to honour the credit by incurring deferred payment or paying for drafts on maturity, but it cannot negotiate its own undertaking as provided by UCP. In such situation, issuing bank will pay in maturity and there is no possibility for beneficiary to be paid in earlier date. Issuing bank also cannot negotiate a credit with drafts drawn on applicant as it is not permitted in UCP for beneficiary to draw drafts on applicant. $^{87}$

\footnotetext{
$85 \quad$ Ibid, p. 115

86 Malek. A, Quest. D, (2009). Op.Cit., p. 115

87 UCP 600-article 6 (c), UCP 500-article 9(a)(iv).
}

Article 6(a) of the UCP 600 provides that credit available with nominated bank is also available with issuing bank; therefore, beneficiary can directly present documents to issuing bank rather than going to nominated bank.

\section{Confirming Bank Undertaking}

(a) Provided that the stipulated documents are presented to the confirming bank or to any other nominated bank and that they constitute a complying presentation, the confirming bank must:

$i$. honour, if the credit is available by:

a. sight payment, deferred payment or acceptance with the confirming bank;

b. sight payment with another nominated bank and that nominated bank does not pay;

c. deferred payment with another nominated bank and that nominated bank does not incur its deferred payment undertaking or, having incurred its deferred payment undertaking, does not pay at maturity;

d. acceptance with another nominated bank and that nominated bank does not accept a draft drawn on it or, having accepted a draft drawn on it, does not pay at maturity;

e. negotiation with another nominated bank and that nominated bank does not negotiate.

ii. negotiate, without recourse, if the credit is available by negotiation with the confirming bank. 
(b) A confirming bank is irrevocably bound to honour or negotiate as of the time it adds its confirmation to the credit.

(c) A confirming bank undertakes to reimburse another nominated bank that has honoured or negotiated a complying presentation and forwarded the documents to the confirming bank. Reimbursement for the amount of a complying presentation under a credit available by acceptance or deferred payment is due at maturity, whether or not another nominated bank prepaid or purchased before maturity. A confirming bank's undertaking to reimburse another nominated bank is independent of the confirming bank's undertaking to the beneficiary.

(d) If a bank is authorized or requested by the issuing bank to confirm a credit but is not prepared to do so, it must inform the issuing bank without delay and may advise the credit without confirmation". ${ }^{88}$

Reviewing Article 7(a) and 8(a) of UCP 600 proves the similarity in content and structure of both articles. Obligations of confirming bank consist of honouring the credit when it is available by sight payment, incurring deferred payment or acceptance. Article 8(a)(i-b) provides that confirming bank also has the obligation of honouring the credit when it is available by sight payment, deferred payment, and acceptance with a nominated bank rejects to act upon its nomination. As it was mentioned before, general review of the obligations of confirming bank and issuing bank show strong similarity between them.

88 UCP 600-Article 8
In the same vein with obligations of issuing bank under Article 7 (a)(v), Article $8(\mathrm{a})(\mathrm{i}-\mathrm{e})$ holds that when the credit is available with another nominated bank with negotiation and the nominated bank does not negotiate, confirming bank has obligation to honour the credit while negotiating the credit under such situation is only a discretionary act for it. ${ }^{89}$ Article 8(a)(ii) imposes obligation on confirming bank to negotiate the credit without recourse when it is available with negotiation by confirming bank. This article has no equivalent in Article 7 and imposes more onerous obligation on confirming bank than nominated bank as nominated bank is not bound to negotiate the credit without recourse. ${ }^{90}$ It worth to mention that obligation of the confirming bank to irrevocably honour or negotiate the credit raise as of the moment of adding confirmation to the credit. ${ }^{91}$

\section{Bank's Duty for Examination, Honouring or Rejection of Presentation}

After presentation of documents by beneficiary to issuing, confirming or nominated, the bank has duty of examining the presentation based on documents, within specified period time mentioned in UCP. ${ }^{92}$ Examination takes place to determine whether or not the presentation is complying with terms of the credit. ${ }^{93}$ Emphasize on necessity for bank to examine presented documents only on the basis of documents on their face has reference to principle of autonomy in order to prevent bank from considering factors like performance of beneficiary under the under-

\footnotetext{
Ellinger, E.P., and Neo, D.S.S. (2010). Op.Cit., p. 116 Ibid

UCP600-Article 8(b)

UCP 600-Article 14 (a); UCP 500-Atricle 13 (a)

UCP 600-Article 14 (b); UCP 500-Atricle 13 (b)
} 
lying contract. ${ }^{94}$

Article 15 of UCP 600 provides:

Complying Presentation: a) When an issuing bank determines that a presentation is complying, it must honour; b) When a confirming bank determines that a presentation is complying, it must honour or negotiate and forward the documents to the issuing bank; c) When a nominated bank determines that a presentation is complying and honours or negotiates, it must forward the documents to the confirming bank or issuing bank.

When bank finds out that documents do not comply with terms of the credit, it has no obligation to honour or negotiate the presentation ${ }^{95}$. In such situation, bank may refer on its discretion to the applicant for waiver. ${ }^{96}$ Decision of bank to reject the presentation requires it to provide beneficiary with a notice of refusal in accordance with form and within the time frame defined by UCP. ${ }^{97}$ Article 16(f) UCP600 provides that in case of failure of issuing bank or confirming bank to act in accordance with procedure of rejection mentioned in Article 16, it will be precluded form claiming based on non-compliance of presentation. ${ }^{98}$ Finally, as result of refusing to honour/negotiation of presentation by issuing/confirming bank, it will be entitled to reimbursement after giving the notice of refusal on the basis of Article 16 of UCP $600 .{ }^{99}$ It should be considered that examination of documents and issuing the notification of rejection are two different requirements. ${ }^{100}$

94 UCP 500-Article 9(a) and 9(b).

95 UCP 600-Article 16 (a); UCP 500-Artcile 14 (b)

96 UCP 600-Article 14 (b); UCP 500-Artcile 13(c)

97 UCP 600-Article 16 (c) and (d); UCP 500-Article 13(b), 14(d) (i) and 14 (d)(ii)

98 UCP 600-Article 16 (f); UCP 500-Article 14 (e)

99 UCP 600-Article 16 (g); UCP 500-Artcile 14(d)(ii)

100 Ellinger, E.P., and Neo, D.S.S. (2010). Op.Cit., p. 119
In UCP 500, Article $13 \mathrm{~b}$ provides that "The issuing bank, the confirming bank, if any, or a nominated bank acting on their behalf, shall each have a reasonable time, not to exceed seven banking days following the day of receipt of the documents, to examine the documents and determine whether to take up or refuse the documents and to inform the party from which it received the documents accordingly". At the same time, Article 14 (d)(i) provides that: "If the Issuing Bank and/or Confirming Bank, if any, or a Nominated Bank acting on their behalf, decides to refuse the documents, it must give notice to that effect by telecommunication or, if that is not possible, by other expeditious means, without delay but no later than the close of the seventh banking day following the day of receipt of the documents. Such notice shall be given to the bank from which it received the documents, or to the Beneficiary, if it received the documents directly from him".

Therefore, there was the possibility under UCP 500 for banks which have done the examination of documents in accordance with Article 13(b) to be precluded from claiming reimbursement as a result of failure in providing notice of rejection "without delay". The concept of reasonable time in examination of presentation is a vague notion and it could be flexible depending of different factors like practice in different parts of the world and also number and complexity of documents. ${ }^{101}$ However, decisions of the Court of Appel in Banker's Trust Co c State Bank of India ${ }^{102}$ and the Supreme Court of Singapore in United Bank Ltd v Banque Na-

\footnotetext{
$101 \quad$ Ibid

102 [1991] 1 Lloyd's Rep 587
} 
tionale de Paris ${ }^{103}$ in addition to formulation of UCP 500 provides that seven days period for examination of documents by bank was the maximum time limit for the most complicated presentations. However, shorter time could be considered for the simpler ones. ${ }^{104}$

This seems to be less problematic under UCP 600 as the Article 14 (b) provides: "A nominated bank acting on its nomination, a confirming bank, if any, and the issuing bank shall each have a maximum of five banking days following the day of presentation to determine if a presentation is complying. This period is not curtailed or otherwise affected by the occurrence on or after the date of presentation of any expiry date or last day for presentation". Article 14(b) clarifies that under UCP 600; bank may perform examination and issue the notice at any time within five banking days and notions of "reasonable time" and "without delay" are no longer relevant. ${ }^{105}$

Application of the Article 16(f) of the UCP 600 can impose severe consequences on bank examining presented documents by beneficiary as it provides that issuing or confirming bank which fail to comply with due procedure of rejection stipulated in Article 16 will be precluded from claiming non-compliance of presentation with terms of credit. Such situation will result in obligation of bank to accept documents and pay for presentation while it will not be eligible for reimbursement by instructing party. ${ }^{106}$ UCP 600 confines preclusion to issuing and confirming bank while not mentioning a word

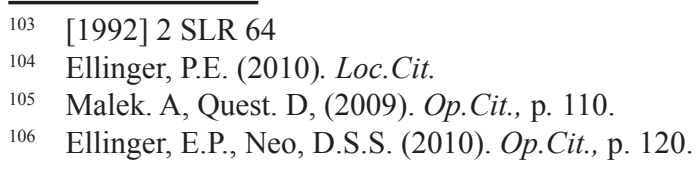

about nominated bank in the same situation. Such position is understandable since nominated bank acts as agent of issuing bank and does not have any obligation to beneficiary regarding honour or negotiation of the credit. ${ }^{107}$ However, according to the agency law, failure of nominated bank in acting upon UCP instructions will affect position of issuing bank to be precluded from reimbursement by applicant. ${ }^{108}$ In return, issuing bank may raise a claim for losses against nominated bank due to breach of mandate and failure to comply with UCP instructions. ${ }^{109}$

In regard with extent of the application of Article 16(f), different court decisions confine it clearly to the documentary discrepancy in the framework of Article 16. Therefore, failure of beneficiary to comply with provisions of Article 16 due to reasons including improper time or place of presentation will not preclude bank from claiming reimbursement from instructing party. ${ }^{110}$

The court of Bayerische Vereins Bank Aktiengesellschaft v. National Bank of Pakistan, ${ }^{111}$ held that Article 13 and 14 of UCP (then UCP 500) only refer to discrepancies on the face of documents. Therefore, as time of presentation cannot be considered as discrepancy on the face of documents, Article 13 and 14 do not apply in case of presentation had been made out of time. ${ }^{112}$ However, issuing or confirming bank which intend to reject the presentation is recommended to mention all discrepancies (documentary and non-documentary) within the notice of

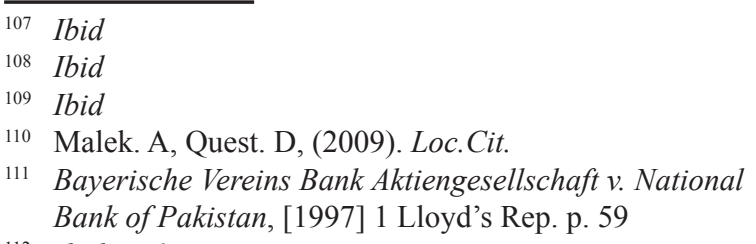


rejection in order to be safe from possible consequences of preclusion by Article 16 (f). ${ }^{113}$ Such recommendation will not apply in cases that bank decides to reject presentation due to committing fraud by beneficiary. Since in case of beneficiary's fraud, there is no discrepancy in documents, bank has no obligation to follow instructions of Article 16. ${ }^{114}$ This is argued that in case of nullity, presentation can be considered as discrepant as beneficiary has the implied duty to present genuine document under the credit and bank will be precluded from reimbursement according to Article 16(f) if it does not provide the proper notice of rejection.

According to common law principles, when the preclusion under UCP is no the matter of concern, it might be held that apart from failing to state discrepancies in notice of rejection, bank has waived or estopped from relying on them. ${ }^{115}$ Also, failure of bank to reject documents within reasonable time can stand for acceptance of presentation. ${ }^{116}$

\section{Liability of Issuing Bank to Beneficiary}

Payment to Incorrect Party

The bank should effectuate payment under the credit to party who is entitled for receiving it. ${ }^{117}$ In case bank pays to the party who is not entitled for receiving the money, the obligation to pay to the entitled party will remain with bank and it should pay once again. ${ }^{118}$ The decision of Cleveland Manufacturing

113 Ellinger, E.P., Neo, D.S.S. (2010). Op.Cit., p. 121.

114 Alavi, H. (2016). "Documentary Letters of Credit, Principle of Strict Compliance and Risk of Documentary Discrepancy". Kor. UL Rev., 19, 3.

115 Malek. A, Quest. D, (2009). Op.Cit., p. 120.

116 Ellinger. P.E (2010), Op.Cit., p. 121.

117 Malek. A, Quest. D, (2009). Op.Cit., p. 129

118 Ibid
Co Ltd v Muslim Commercial Bank ${ }^{119}$ is a good example. In the case of Cleveland, plaintiffs instructed shipping agents to prepare and present documents to defendant bank. The bank effectuated payment to shipping agents but they did not pay beneficiary as a result of getting liquidated. Since shipping agents were not agents of beneficiary, plaintiff succeeded in court against the bank.

\section{Late Payment}

In English law, when there is a delay in making payment by bank, beneficiary should prove his loss is recoverable under ordinary rules of causation plus remoteness of damages to get favourable ruling from the hearing. ${ }^{120}$ In the case of Ozalid Group (Export) Ltd v African Continental Bank Ltd, ${ }^{121}$ bank made the payment of US\$125,939 to beneficiary English Company) with two months of delay. As during above mentioned period USD depreciated against Pound and due to existing exchange rate controls on that time, company had to convert its dollars to sterling. The court ordered in favour of beneficiary and they recovered sterling value of dollars between the time that they were supposed to be received and time that they actually received, plus interest of total sum during two months of delay and reasonable costs incurred by sellers in attempt to collect payment.

In International Minerals and Chemical Corpn v Karl O Helm AG ${ }^{122}$ in absence of exchange regulations, plaintiff (an English company) should prove that they have

119 [1981] 2 Lloyd's Rep 646

120 Malek. A, Quest. D, (2009). Op.Cit., p. 128

121 [1979] 2 Lloyd's Rep 239

122 [1986] 1 Lloyd's Rep 81, P105 
converted UDSs to Sterling at the same time or after their receipt due to company financial policy in order to justify their loss. Therefore, it was sufficient to satisfy the test of the likelihood (remoteness) of damage which was also recited in the House of Lord decision of Koufus $v$ C Carnikow Ltd ${ }^{123}$. At present time, claims for interest where banks pay with delay (but before beginning of court proceeding) is governed by the decision of the House of Lard in Sempra Metals Ltd v IRS. ${ }^{124}$ Accordingly, court would have jurisdiction under common law "to award compound and simple interest on claims for breach of a contract to pay a debt"125. Recovery of actual interest lossed due to breach of contract by bank will be conditional to beneficiary's capability to provide proof of loss, satisfy tests of the remoteness of damages, oblations for mitigating damages and other relevant rules. ${ }^{126}$

\section{Non-Payment}

Bank has the obligation to honour the conforming presentation. In case of dishonouring the conforming presentation and rejection of bank to pay against complying documents, beneficiary has the right to sue it provided that seller beneficiary remains capable of tendering documents to bank against payment. ${ }^{127}$ Even in case of non-compliance of documents if issuing or confirming bank does not follow the guidelines for examination and rejection of documents provided in Articles 7 and 8 of UCP 600 will be pre-

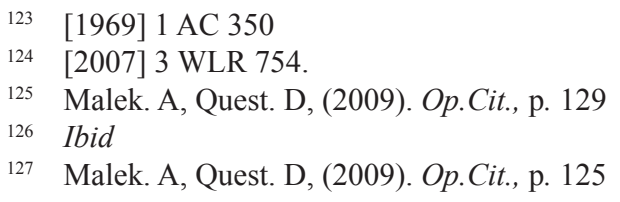

cluded from rejection of presentation. ${ }^{128}$ In effect, wrongful dishonour of the presentation by bank means non-payment of amount due on beneficiary under the credit. In such situation, beneficiary has two different bases for his claim against bank: first one is to bring action against bank and aim for damages resulting from breach of bank's obligation. Second, is bringing an action in debt of the sum due under the credit. ${ }^{129}$ Although, beneficiary might take either of actions, courts seem to treat both actions as the same manner. Greer J in Dexters Ltd $v$ Shenker \& Co., ${ }^{130}$ mentioned:

"...the date of the payment has passed and the payment has not been made, the way to read the claim of this sort is that it is the claim for damages for non-payment of money, and in ninetynine out of hundred cases the amount of damages will be the sum which there has been the undertaking to pay." 131

In practice, beneficiary will incur loss equal to the price mentioned in the credit ${ }^{132}$ and interest due to delay in payment. This amount will be similar to what can be required under the claim in debt. However, it is submitted that claim in damages might have more effect and result higher awards. ${ }^{133}$ General principles of English contract law provides that "injured party will be awarded damages which put him in a position that he would have been in has the contract been performed". ${ }^{134}$ Where there is claim for consequential losses incurred due to the breach

\footnotetext{
${ }_{128}$ Ellinger, E.P., Neo, D.S.S. (2010). Op.Cit., p.122 129 Ibid

130 (1923) 14 Lloyd's Rep

131 Ibid., p. 586

132 English Imex Industries Ltd v Mainland Bank Ltd [1958] 1 QB 542

133 Ellinger, E.P., Neo, D.S.S. (2010). Op.Cit., p.123

134 Ibid
} 
of contract, such losses will be recovered if claimant manages to satisfy rules of the remoteness of damage. ${ }^{135}$

In Prehn v. Royal Bank of Liverpool, ${ }^{136}$ defendant bank rejected the draft drawn on it despite its acceptance at beginning. The court considered case as breach of contract of honouring drafts which became due and ordered in favour of claimants the amount of draft in addition to cost of purchasing fresh drafts from other bank, cost of cable and expenses in protesting the drafts. In Urquhart Industry and Co. Ltd. v. Eastern Bank $L t d,{ }^{137}$ the case was about sale of machinery which was manufactured and shipped by beneficiary seller in different instalments. Defendant bank opened the credit in favour of beneficiary but, rejected honouring a bill despite being presented together with complying documents. The court held that due to bank's refusal beneficiary does not need to continue shipment of future instalments. Therefore, beneficiary should consider the contract terminated and sue in accordance with loss in the whole contract. ${ }^{138}$ From this case, it is possible to comprehend that issuing bank's breach of obligations to pay under the credit would be considered equal to repudiation of applicant under the contract of sales with beneficiary. ${ }^{139}$

It has been submitted that claim for damages resulting from breach of contract has a disadvantage of existence of expectations from claimant to mitigate his losses. ${ }^{140}$ This means that beneficiary facing

135 Prehn v. Royal Bank of Liverpool (1870) LR 5 Ex 92.

136 Ibid

137 Urquhart Industry and Co. Ltd. v. Eastern Bank Ltd [1922] 1 KB 318

138 Ibid., p. 324

139 Ellinger, E.P., Neo, D.S.S. (2010). Op.Cit., p. 124

140 Malik. A (2009), Op.Cit., p. 120 with wrongful dishonour of credit by issuing bank will try to sell goods to other buyer and cover his losses partially. However, such argument does not comply with fundamental principles of LC as beneficiary is guaranteed to receive payment from issuing bank after presentation of complying documents with terms of the credit and as a result, mitigation principle has not received any support in court's decisions. ${ }^{141}$ In Belgian Grain and Produce Ltd v. Cox \& CO. (France) Ltd., ${ }^{142}$ Banks LJ held that "requirement for mitigation would defeat the object of the letter of credits which is to avoid controversies as to damages. It would also be contradictory to the fundamental understanding between the bank and the beneficiary that the letter is entitled to be paid as long as he makes a confirming presentation under the credit". ${ }^{143}$

For beneficiary to win the claim against wrongful dishonour of issuing bank it is necessary to prove that presentation was complying with terms of the credit. However, there is always some inherent uncertainty that court to rule in his favour. ${ }^{144}$ Also in case of dealing with perishable goods or high storage costs, the time lag between dispute and rendering the judgment by court will be against interests of beneficiary. Therefore, one solution can be selling his goods and then suing the issuing bank for difference between the price of resale and amount of credit. ${ }^{145}$ An alternative solution would be applying for expedited hearing

\footnotetext{
${ }^{141}$ Belgian Grain and Produce Ltd v. Cox \& CO. (France) Ltd., (1919) 1 Lloyd's Rep 256; Stein v. Hambros Bank of Nothern Commerce, (1921) 9 Lloyd's Rep 433.

142 (1919) 1 Lloyd's Rep 256

143 Ellinger. P.E. (2010). Loc.Cit.

144 Ibid

145 Malik. A (2009). Loc.Cit.
} 
from the court. ${ }^{146}$ In British Imex Industries Ltd v Midland Bank Ltd., ${ }^{147}$ presentation of documents for the sale of steel bars rejected by bank on 10 December, hearing started on 11 of December and decision was rendered if favour of beneficiary on 20 December. ${ }^{148}$ Third solution can be opening a joint account for beneficiary and issuing bank in order to deposit the money from reselling goods if it is easy to sell them. ${ }^{149}$ However, this will be difficult option when goods are custom made or not ready for market. Finally, if no action is taken, loser will take all the loss and this is really rare for beneficiary to be so sure about his claim not to act upon reselling the products. ${ }^{150}$

Under English law, payment of the credit by acceptance which means conjunction of drafts to the credit will subject it to the rules of the bills of exchange. Section 57 (1) of Chapter 61 of the Bills of Exchange Act 1882 holds that bank which dishonours an already accepted draft is liable for damages that will be calculated based on the amount of the bill, plus interest and cost of protest and noting. Where draft is discounted by beneficiary and accepted by the drawee bank, the holder of draft will be eligible to sue for wrongful dishonour of it by bank. ${ }^{151}$

\section{Issuing Banks Right to Recourse against Beneficiary}

In certain situations, issuing or confirming bank might seek recovery from beneficiary

\footnotetext{
146 Ibid

147 British Imex Industires Ltd v Midland Bank Ltd [1958] 1 QB 542

148 Malik. A (2009). Loc.Cit.

149 Ellinger. P.E (2010). Loc.Cit.

${ }_{150}$ Ibid

${ }^{151}$ Ibid, p. 128
}

after paying to him. According to Jack, ${ }^{152}$ most probable of such situations can be: First and foremost possibility is when the bank examines presentation, finds documents compliant to terms of the credit and effectuates the payment to beneficiary. However, it will be found subsequently that documents are discrepant and bank is not entitled for reimbursement; Second is when applicant files for bankruptcy and will not be able to reimburse the issuing bank after honouring the credit; and third situation might be the occasion that bank has negotiated the credit and draft drawn on the applicant and draft will be dishonoured later.

The general view is that bank (issuing/ confirming) will not have any right for receiving reimbursement from beneficiary as it is against the principle of documentary letters of credit to provide a secure means of payment for beneficiary. Therefore, recourse rights against beneficiary may not exist.

\section{Complying Presentation}

Where bank has paid beneficiary against complying documents to terms and conditions of the credit, and then applicant refuses to reimburse the bank for any given reason, bank will not have any cause of action against beneficiary under UCP or common law. ${ }^{153}$ Bank is supposed to check the credit worthiness of applicant before issuing the credit and beneficiary is not by any means concerned regarding applicant's impecuniousness. Issuing bank should take an action against applicant instead of trying to take the money back from beneficiary. However, it is submitted that since bank is gener-

152 Malek. A. (2009), Op.Cit., p. 129

153 Ellinger. P.E. (2010), Op.Cit., p. 133 
ally in possession of documents of title under the letter of credit, it can compensate part of loss by reselling goods. ${ }^{154}$

\section{Non-Complying Presentation}

When the UCP applies, the position is that bank does not have any obligation to pay beneficiary against presentation of non-complying documents. The issuing bank which fails to examine and reject non-complying presentation in accordance with procedure explained in Articles 7 and 8 of UCP 600 will be precluded from raising any claim about discrepancy of documents. ${ }^{155}$ This is clear position of UCP to prevent bank from raising any claim on non-compliance of documents to terms of credit after certain number of days passing from presentation. ${ }^{156}$ Therefore, issuing bank is bound ${ }^{157}$ by provisions of UCP to pay the beneficiary in case of failure to reject presentation due to discrepancy of documents.

Where UCP is not corporated or relevant provisions of it are excluded then situation will be governed by general principles of common law. ${ }^{158}$ On the basis of contractual obligations, beneficiary will be entitled to payment after presentation of complying documents. Therefore, bank can avoid payment when the presentation is noncomplying. Therefore, if beneficiary is paid under such circumstances, under common law principles, bank is entitled to claim for "restitution of money paid under mistake". ${ }^{159}$ Alternatively, issuing bank can raise a claim

\footnotetext{
$154 \quad$ Ibid

155 UCP 600-Artilcle 16(f)

156 Ellinger. P.E. (2010). Loc.Cit., p. 133

157 Ibid

158 Ibid

159 Ibid
}

for restitution of money paid to beneficiary based on mistake when the beneficiary is paid but was not entitled for payment or because of committing fraud. ${ }^{160}$

\section{Bills of Exchange}

Where bills of exchange are included in the credit, law of negotiable instruments will be relevant under English law. In such situation, issuing bank is the drawee of the draft and undertakes to honour the credit upon presentation of complying documents by beneficiary. Therefore, issuing bank will not have any right of recourse against beneficiary as drawer of the draft. Alternative possibility is when issuing bank undertakes to negotiate drafts drawn on the applicant by beneficiary after presentation of complying documents despite the fact that drafts are not allowed to be drawn on applicant under UCP. ${ }^{161}$ In such a situation (which is possible if parties decide to exclude relevant provisions of UCP), Section 43 (2) or 47 (2) of the Bill of Exchange Act (1882) possibly will give the issuing bank (as the holder or endorsee of the draft) right to recourse against beneficiary (drawer) when applicants (drawee) rejects to pay it. ${ }^{162}$

\section{Fraud and Misrepresentation}

Since UCP takes a silent approach to fraud, fraud and other expectations to principle of independence in documentary letters of credit are governed by national law. ${ }^{163}$ In

\footnotetext{
160 Niru Battery Manufacturing Co and Another v Milestone Trading Ltd and Others [2004] QB 985.

161 UCP600, Article 6 (c); UCP 500-Article 11 (b) (iv)

162 Ellinger, P.E (2010), Op.Cit., p. 135

163 Alavi, H. (2015). "Autonomy Principle and Fraud Exception in Documentary Letters of Credit, a Comparative Study between United States and England". International and Comparative Law Review, 15(2): 45-67
} 
English law, there will be no legal problem on the way of issuing bank to claim for restitution against beneficiary in the case of fraud. In case of committing fraud by beneficiary, issuing and confirming bank will have right to claim for restitution against beneficiary on the basis of the tort of deceit. ${ }^{164}$ The difference under American law is that while getting paid, beneficiary provides bank with warranty that no fraud or forgery is involved and if contrary is proved, and then bank will have the right for restitution as a result of the breach of warranty. ${ }^{165}$ However, where the fraud is not involved, it would be difficult for issuing/confirming bank to get restitution based on negligent misrepresentation of the beneficiary. ${ }^{166}$ It was held in DBS Bank Ltd v Carrier Singapore: ${ }^{167}$

"If were to accept ... that the bank may rely on negligent misrepresentation by beneficiary to recover any money it had paid out to the beneficiary, the law would also have to accept that banks are also entitled to invoke negligent misrepresentation by the beneficiary as a ground for not paying the beneficiary at first place. The practical effect of this would be to unravel the narrow fraud exception the House of Lords [in United City Merchants] took pains to limit; banks could refuse to pay the beneficiary once there was any inaccurate statement of material fact by simply alleging that the beneficiary had been negligent. One has to bear in mind that the underlying foundation of the system of documentary credits is to give sellers as far as possible, an "assured right" to payment notwithstand-

\footnotetext{
164 Derry v Peek (1889). 14 App Cas 337

165 Ellinger, P.E (2010), Op.Cit., p.136

166 DBS Bank Ltd v Carrier Singapore (Pte) [2008] 3 SLR 261

167 Ibid, p. 99-100
}

ing disputes in the underlying sale contract... in my view developing the law to allow for the negligent misrepresentation exception would be an unjustified erosion of this very promise. Documentary credits must be allowed to be honoured as far as possible, free from interference form the courts. Otherwise trust in international commerce could be irreparably damaged". ${ }^{168}$

The decision in DBS Bank Ltd v Carrier Singapore proposed that bank or applicant can raise an action against beneficiary for negligent misrepresentation when the issuer of document provides warranty for documents as accurate to either issuing or confirming bank or applicant. ${ }^{169}$ However, agreement of beneficiary to terms of LC in normal situation "is an insufficient material from which to imply any such assumption of responsibility". ${ }^{170}$

\section{CONCLUSION}

In practice of international trade, documentary letters of credit are in circulation for many centuries. Their existence, popularity and unique model of functioning are proves for their effectiveness in addressing relevant problems to payment risk in international trade finance. Despite numerous efforts of legal experts and academic scholars in defining unclear aspects in complicated process of LC operation, there are yet uncertainties in areas including issuing bank relations with beneficiary. As an interesting and controversial problem, issuing bank's obligations towards beneficiary were scrutinized as the subject matter of current paper. Starting with legal nature of issuing bank's obligation to

\begin{tabular}{ll}
\hline 168 & Ibid. \\
169 & Ibid, p. 104 \\
170 & Ibid.
\end{tabular}


pay beneficiary, author got to the result that payment obligation of bank to beneficiary is regulated by mercantile usage as UCP does not touch upon the problem and none of contract law theories in common law system are not capable of addressing absence of movement of consideration from beneficiary to issuing bank properly. Further, examination, honour and rejection process of beneficiary's presentation by (issuing/confirming) bank as main obligations towards beneficiary were discussed and relevant case law was considered. In continuation, principle liabilities of issuing bank towards beneficiary were defined under three headings of wrongful dishonour of personation, late payment and payment to wrong party. Last but not the least, discussion of conditions under which bank has right to recourse for restitution of money paid to beneficiary under common law provisions and UCP showed that unlike common law, UCP does not provide issuing bank with right to recourse based on payment under mistake when presentation is complying. Finally, in case of fraud bank has right for recourse against beneficiary under common law provisions where UCP is taking an absolute silent stance.

\section{BIBLIOGRAPHY}

Alavi, H. (2015). "Autonomy Principle and Fraud Exception in Documentary Letters of Credit, a Comparative Study between United States and England". International and Comparative Law Review, 15(2): 45-67.

Alavi, H. (2016). "Documentary Letters of Credit, Principle of Strict Compliance and Risk of Documentary
Discrepancy”. Kor. UL Rev., 19, 3.

Baker B. "Exporting Against Letters of Credit". Available online at: http://www.qfinance.com/content/Files/QF02/g1xtn5q6/12/3/exporting-againstletters-ofcredit.pdf (Accessed on 10 May 2016)

Banker's Trust Co v. State Bank of India [1991] 1 Lloyd's Rep 587

Bayerische Vereins Bank Aktiengesellschaft v. NationalBank of Pakistan, [1997] 1 Lloyd's Rep. 59

Beale, H. (2012). Chitty on Contracts. Chicago: Sweet \& Maxwell.

Belgian Grain and Produce Ltd v. Cox \& CO. (France) Ltd., (1919) 1 Lloyd's Rep 256

Bollen, R. (2007). "An Overview of the Operation of International Payment Systems with Special Reference to Australian Practice: Part 1", Journal of International Banking Law and Regulation, 22(7), 381.

Botosh, H.M.S. (2000). 'Striking the Balance Between the Consideration of Certainty and Fairness it the Law Governing Letters of Credit'. Ph.D thesis, University of Sheffield.

British Imex Industires Ltd v Midland Bank Ltd [1958] 1 QB 542

Buckley, R et al., (2002). "Development of the Fraud Rule", 23 U. Pa. J. Int'l Econ. L. 698.

Bunge Corporation v. Vegetable Vitamin Foods (Private) Ltd [1985] 1Lylod's Rep. 613

Carr, I., \& Stone, P. (2014). International Trade Law, $5^{\text {th }}$ Edition. New York: Routledge.

Cleveland Manufacturing Co Ltd v Muslim 
Commercial Bank [1981] 2 Lloyd's Rep 646.

Davis, A.G, (1963), The Law Relating to Commercial Letters of Credit, $3^{\text {rd }} \mathrm{edn}$, London: Isaac Pitman \& Sons Ltd.

Davis. A.G, (1936), 'The Relationship between Banker and Seller under a Confirmed Credit', 52 LQR 225.

DBS Bank Ltd v Carrier Singapore (Pte) [2008] 3 SLR 261.

Derry v Peek (1889). 14 App Cas 337.

Dexters Ltd v Shenker \& Co (1923) 14 Lloyd's Rep.

Dighe, K.S, (1992). "Mercantile Speciality: A Theory by which to Enforce Letters of Credit Under the Common Law". University of Detroit Mercy LR, 69, 211.

Eakin v Continental Illinois National Bank \& Trust Co. (1989) 875 F.2d 114.116.

Ellinger, E.P. (1970). Documentary Letters of Credit: A Comparative Study, Singapore: Singapore University Press.

Ellinger, E.P., and Neo, D.S.S. (2010). The Law and Practice of Documentary Letters of Credit. Oxford: Hart Publishing.

Ellinger, P.E (1983), “The Autonomy of Letters of Credit after the American Accord", Australian Business Law Review, 11(2), 118.

English Imex Industries Ltd $v$ Mainland Bank Ltd [1958] 1 QB 542

Garcia v. Page \& Co. Ltd (1936) 55 LI.LR 391

Goode, R, (1988). "Surety and On-Demand Performance Bonds", J. Bus. L. 88.

Goode, R. (1995). Commercial Law. $2^{\text {nd }}$ ed, London: Penguin, p. 987
Grassi, P. (2006). "Letter of Credit Transactions: The Banks' Position in Determining Documentary Compliance. A Comparative Evaluation under U.S., Swiss and German Law", Pace International Law Review, 7(81), 122.

Gutteridge, H.C., Megrah, M. (1984). The Law of Bankers' Commercial Credits. $7^{\text {th }}$ ed, London: Europa Publications Ltd.

Hugo, C. (2000). "Documentary Credits: The Basis of the Bank's Obligation”. S. African LJ, 117, 224-230.

International Minerals and Chemical Corpn v Karl O Helm AG [1986] 1 Lloyd's Rep 81, P105.

Jack, R. (2003). Documentary Credits: The Law and Practice of Documentary Credits Including Standby Credits and Performance Bonds. UK: Butterworths.

King, R (ed). (2001), Gutteridge and Megrah's Law of Banker's Commercial Credit, $8^{\text {th }}$ edn, Europa Publication.

King, R. (2003). Gutteridge and Megrah's Law of Bankers' Commercial Credits. UK: Routledge.

Koufus v C Carnikow Ltd [1969] 1 AC 350

Leacock, S.J. (1984). "Fraud in the International Transaction: Enjoining Payments of Letters of Credit in International Transactions", Vand. J. Transnatl. L. 17, 898 .

Lipton, J.D. (1998). “Documentary Credit Law and Practice in the Global Information Age", Fordham International Law Journal, 22(5): 1972-1990.

Malek, A, Quest. D, (2009). Jack: Documentary Credit: The Law and Practice of 
Documentary Credit including Standby Credits and Demand Guarantees, $4^{\text {th }}$ Edition, UK: Tottel Publishing.

McCormack, G et al., (2000). "Subrogation and Bankers' Autonomous Undertakings", 116 Law Quarterly Review 141. McCurdy, W. (1922). "Commercial Letter of Credit", Harvard Law Review, 35, 539.

McKendrick, E (ed). (2010). Goode on Commercial Law, $4^{\text {th }}$ edn, London: Penguin.

Megrah, M. (1982). "Risks Aspects of the Irrevocable Letter of Credit", Ariz. L. Rev. 24, 260.

Neo, D.S.S. (2004). "A Nullity Exception in Letters of Credit Transactions?" Singapore Journal of Legal Studies, 49.

Niru Battery Manufacturing Co and Another v. Milestone Trading Ltd and Others [2004] QB 985.

Ozalid Group (Export) Ltd v. African Continental Bank Ltd [1979] 2 Lloyd's Rep 239

Pavia \& Co SpA v. Thurmann-Nielsen [1952] 2 Q.B. 84.

Penn, G.A., A.M. Shea., and Arora, A. (1987). The Law and Practice of International Banking. $4^{\text {th }}$ Edition. UK: Sweet \& Maxwell.

Pollway Ltd v Abdullah [1974] 2 All ER 381 (CA).
Prehn v. Royal Bank of Liverpool (1870) LR 5 Ex 92.

Schmitthoff, C.M. (1988). "The Transferable Credit”, Journal of Business Law, 51.

Sempra Metals Ltd v IRS [2007] 3 WLR 754

Stein v. Hambros Bank of Nothern Commerce, (1921) 9 Lloyd's Rep 433.

Todd, P. (1983). "Sellers and Documentary Credit", Journal of Business Law, 468.

Treitel, G.H. (2003). The Law of Contract. $11^{\text {th }}$ edition. UK: Sweet \& Maxwell.

Trimble, R.J. (1948). "The Law Merchant and the Letter of Credit", Harvard Law Review 61, 981-1006.

Tweddle v Atkinson [1861-73] All ER Rep 369 (QB)

United Bank Ltd v Banque Nationale de Paris [1992] 2 SLR 64

United City Merchants (Investments) Ltd. v. Royal Bank of Canada, [1932] 2 W.L.R. 1039, H.L.

Urquhart Industry and Co. Ltd. v. Eastern Bank Ltd [1922] 1 KB 318

Ward Petroleum Corp. v Federal Deposit Ins. Corp. (1990) 903 F.2d 1299.

Zhou. L. (2002). "Legal Position between Advising Bank and Confirming Bank: Contrast and Comparison", Journal of International Banking Law, 17(7): 226. 